Egyptian Journal of Aquatic Biology \& Fisheries

Zoology Department, Faculty of Science,

Ain Shams University, Cairo, Egypt.

ISSN $1110-6131$

Vol. 24(6): 225 - 242 (2020)

www.ejabf.journals.ekb.eg

\title{
Effect of different doses of human chorionic gonadotropin (HCG) hormone on stripping response and reproductive performance of the African catfish (Clarias gariepinus).
}

\author{
Sayed R. S. Zidan ${ }^{1 *}$, Hamed H. E. Saleh ${ }^{2 *}$, Ahmed I. Semaida ${ }^{1}$, \\ Ramadan M. Abou-Zied ${ }^{1}$ and Sobhy M. Allam ${ }^{1}$ \\ 1. Animal Production Department, Faculty of Agriculture, Fayoum University, Egypt. \\ 2. Aquaculture Division, National Institute of Oceanography and Fisheries, El-Fayoum, Egypt. \\ *Corresponding authors: srs11@fayoum.edu.eg \\ hhsaleh90@gmail.com
}

\section{ARTICLE INFO}

Article History:

Received: July 19, 2020

Accepted: Sept. 2, 2020

Online: Sept. 9, 2020

Keywords:

African catfish, HCG hormone, gonadsomatic index, latency period, fertilization rate, hatching rate

\begin{abstract}
This study was conducted to investigate the effect of different doses injection of human chorionic gonadotropin (HCG) hormone on stripping response and reproductive performance of African catfish (Clarias gariepinus). African catfish spawners were intramuscularly injected with different doses of HCG $(500,1500$, $3000,6000 \mathrm{IU} / \mathrm{kg}$ female); males were injected at half the female dose. The results showed that fish group injected by $6000 \mathrm{IU} / \mathrm{kg}$ female had the highest ovaries weight and gonadsomatic index, but, recorded the lowest value from ovulated egg diameter. The lower latency period was recorded with $6000 \mathrm{IU} / \mathrm{kg}$ female $(12 \mathrm{~h})$. While, the highest latency period were in 500, $1500 \mathrm{IU} / \mathrm{kg}(28 \mathrm{~h})$ and $3000 \mathrm{IU} / \mathrm{kg}$ $(22 \mathrm{~h})$. The number of fertilized eggs/ female and fertilization rate (\%) were significantly different $(\mathrm{P} £ 0.05)$ among the experimental treatments, with the highest number of fertilized eggs/ female and fertilization rate were observed with $6000 \mathrm{IU} /$ $\mathrm{kg}$ female (60848 fertilized eggs/ female with $84.45 \%)$ and the lowest number of fertilized eggs/ female and fertilization rate were presented with $500 \mathrm{IU} / \mathrm{kg}$ female (3372 fertilized eggs/ female with 10.15\%). The number of larvae/ female and hatching rate showed significant differences (P£0.05) among different level of HCG hormone with the highest number of larvae and hatching rate with $6000 \mathrm{IU} / \mathrm{kg}$ female (49657 larvae/ female with $81.45 \%$ ) followed by those $3000 \mathrm{IU} / \mathrm{kg}$ female (43177 larvae/ female with 73.65\%), 1500 IU/ kg female (12099 larvae/ female with $57.9 \%$ ), while the incubation eggs of group injected with $500 \mathrm{IU} / \mathrm{kg}$ female don't show any hatching larvae. It was observed, HCG hormone has successfully and accelerate induced spawning in African catfish (Clarias gariepinus)and increased in reproductive performance with the increase in HCG dosage.
\end{abstract}

\section{INTRODUCTION}

Egyptian aquaculture has recently achieved a great successful story setting Egypt on the sixth rank of the world aquaculture (1561.5 thousand tonnes, live weight with $1.90 \%$ of world total aquaculture) and first among African countries (FAO, 2020). Egyptian aquaculture was depended on little number species, Tilapia, Carp and Mullet which 
accounting about $95 \%$ from the production, this led to a lack of diversity in aquaculture. Fortunately, African catfish farming has witness an increased production and gained a substantial importance in the aquaculture sectornewly in Egypt.

The African catfish (Clarias gariepinus) is one of the most important freshwater fish in Africa that has a widely distribution among African countries and has been introduced and cultured in many countries in Asia, Europe and South America (Marimuthu, 2019), due to its many advantages, high growth rate, low production cost, cultured under several systems, extremely resistant to diseases and stress. Catfish $(C$. gariepinus) is a strong fish, where it has tolerance with hard environmental conditions (e.g muddy, high stocking densities and decreasilly in water quality) (Mehrim et al., 2014; Tyor and Pahwa, 2017). All of this advantages, turned African catfish from mere an undesirable species in tilapia ponds or a 'police-fish' to control overbreeding in mixed-sex tilapia culture to an important and potentially species for aquaculture.

With farmers increase more interested in this species, the demand for seed increases, in contrast, the scarceness of natural spawning in captivity. In addition the many problems of collecting fry from nature resources, which are represented in: seasonality, limited, time-wasting, stressful, its productivity is difficult to predict and uneconomic, since the seed availability is the chokepoint for successful culture of any fish species. Accordingly, spawning induction of captive African catfish becomes the best method to conquer this problems, improving in fertilization, hatching, survival rate, possibility to produce fry round all year, through injection of one of several hormones including; fish pituitary extracts, HCG hormone, gonadotropin hormone (GTH), luteinizing hormone-releasing hormone (LHRH) and LHRH agonists (LHRHa), gonadotropin-releasing hormone $(\mathrm{GnRH})$ and GnRHa, Ovatide, Dagin, Ovaryprim, Ovaprim, Ovopel, Ovupin-L, Ovulin and Aquaspawn (Rutaisire and Booth, 2004; Ngueku, 2015; Mamndeyati et al., 2018; Sukendi et al., 2019).

Hormone-induced spawning of fish has been used for almost 60 years in fish hatcheries for production of fry or fingerlings which contributes significantly to the overall aquaculture production (Rahman et al., 2011). It has opened the door of a new era throughout the world for high quality and high quantity of fish production (DOF, 2014). In Africa induced breeding started after the Second World War, which the first successful production of fingerlings was that of Clarias garepinus in Egypt (Aliwa, 1982). Surprisingly, the same procedures, with only minor modifications, have been used to spawn an entire range of fishes from the ancient sturgeon and paddlefish to carp, catfish, salmon, sea bass, sea bream and mullet. In addition to breeding other desirable fish species, Induction of spawning using hormones provides a direct control over the final stages of the reproduction cycle in teleosts (Rottman et al., 1991a).

Spawning induction of $C$. gariepinus has gained a significant international interest by many authors (Brzuska et al., 1999; Brzuska, 2003; Brzuska, 2004; Adebayo and popoola 2008; Maradun et al. 2018); recently in Egypt (Saadony et al., 2014; El-Hawarry 
et al., 2016; Shourbela et al., 2020). In the other hand, the use of HCG is the popular protocol to induce spawning in many fish species such as Sea bream, Sparus aurata (Badran et al., 2019); male Japanese eel, Anguilla japonica (Tanaka et al., 2003); Benni, Barbuss sharpeyi (Kahkesh et al., 2010); Pigfish, Orthopristis chrysoptera (Di Maggio et al., 2014). The stimulation of final oocyte maturation, ovulation and spawning of African catfish by using of human chorionic gonadotropin (HCG) was presented by many authors (Saadony et al., 2014; Mehrim et al., 2014; El-Hawarry et al., 2016; Ahmed, 2018).

The objective of the present study was, to evaluate the overall effects of different doses injection of human chorionic gonadotropin (HCG) hormone on stripping response and reproductive performance of African catfish (Clarias gariepinus Burchell, 1822).

\section{MATERIALS AND METHODS}

The present study was carried out at the Fish Farm in Agricultural Consulting Center, Faculty of Agriculture, El-Fayoum University, Egypt, in August 2019. This study was conducted to investigate the effect of different doses injection of human chorionic gonadotropin (HCG) hormone for improving artificial propagation of African catfish (Clarias gariepinus Burchell, 1822).

\section{Broodstock- rearing conditions.}

African catfish (Clarias gariepinus) broodstock (420-670 g/ fish, body weight) used in this study were purchased alive and in good condition from private fish farm, ElFayoum Governorate, Egypt, then transported to the area where the study was occurred. The brood fish were disinfected with formaldehyde $(0.15 \mathrm{ml} / 10 \mathrm{~L}$ of water, i.e. $15 \mathrm{ppm})$ for 6 hours, and then stock and maintained the female fish separated from the male fish in rectangular tanks $\left(3 \times 2 \times 1.2 \mathrm{~m}^{3}\right)$, supplied with aerated water, where tanks water was continually replaced for 14 days for fish acclimatization to farm water conditions. Fish were held under natural photoperiod condition throughout the experimental period. The average water quality criteria in broodstock tanks are presented in Table (1).

\section{Selection of broodfish.}

Twenty (20) ripe females and Twenty (20) ripe males with sex ratio (1:1 male $\delta^{\lambda}$ : female + ) were selected for the breeding experiment. Ripeness of females was determined by external morphological characteristics the females had a soft, distended abdomen and round swollen genital papilla and readiness to spawn. For proper selection of the female broodfish, a catheter was used to get a small egg sample from their ovaries. The egg diameter of more than $90 \%$ of the ripe ovaries was bigger than $900 \mu \mathrm{m}$ when examined under a calibrated ocular micrometer. The reddening of the genital papilla was used as an indicator of ripeness the males (Ngueku, 2015; Gadisa, 2017; Shourbela et al., 2020). No feed were offered for fish before hormonal injection for three days. The total length $(\mathrm{cm})$ of the brooders was measured with a fish Measuring Board and weight in grams (g) was determined with an electronic scale of all brooders prior to hormone administration. 
Table (1). Water quality criteria of broodstock tanks.

\begin{tabular}{|l|c|}
\hline Parameters & Measurement for broodstock tank \\
\hline Temperature, ${ }^{\circ} \mathrm{C}$ & 29.5 \\
\hline $\mathrm{pH}$ & 8.15 \\
\hline Dissolved oxygen, $\mathrm{mg} / \mathrm{l}$ & 6.37 \\
\hline $\mathrm{EC}^{*}, \mathrm{mS} / \mathrm{cm}^{* *}$ & 3.14 \\
\hline Carbonate $\left(\mathrm{CO}_{3}\right), \mathrm{mg} / \mathrm{l}$ & 32.55 \\
\hline Bicarbonate $(\mathrm{HCO}), \mathrm{mg} / \mathrm{l}$ & 206.35 \\
\hline Total alkalinity, mg/l & 238.9 \\
\hline Calcium $(\mathrm{Ca}), \mathrm{mg} / \mathrm{l}$ & 37.45 \\
\hline Magnesium $(\mathrm{Mg}), \mathrm{mg} / \mathrm{l}$ & 55.35 \\
\hline Hardness $(\mathrm{Ca}+\mathrm{Mg}), \mathrm{mg} / \mathrm{l}$ & 92.8 \\
\hline
\end{tabular}

* Electrical conductivity $\quad * * \mathrm{mS} / \mathrm{cm}$, millisiemens/centimeter

\section{Experimental design and hormonal injection.}

The male and female brooders were grouped into four treatments with five replicates each. The treatments with female to male ratios were $\left(1: 1\right.$ male $\delta^{\lambda}$ : female $\left.q\right)$. African catfish (Clarias garipains) spawners were intermuscularly injected by human chorionic gonadotropin (HCG) hormone, the commercial name is (choriomon ${ }^{\circledR}$ ). This hormone is one of the most hormone used in human medicine as a stimulator to ovary, the HCG hormone was produced by a commercial pharmaceutical company (Sumach: Infar, India) and HCG solution was prepared according to the prescriptions of brochure supplied by the manufacturing company, it is freeze-dried powder corresponding to 5000 IU HCG per vial, the HCG hormone extracted from human urine; the origin of the urine; people's republic of china.

The experimental fish (female and male) were injected after weighted it to determine the dose of hormone according to dose of each group (Table 2). Then they intramuscularly injected at angle 30- 45 degrees by insulin syringes into the dorsal muscle above the lateral line toward the tail (El-Hawarry et al., 2016). The injection was made in the evening between $5 \mathrm{pm}$ and $6 \mathrm{pm}$, and after that, the injected females were returned into the containers until the checking for ovulation.

Table (2). Details of the experimental treatments (fish injection by HCG).

\begin{tabular}{|c|c|c|c|c|}
\hline \multirow{2}{*}{ Treatments } & \multicolumn{2}{|c|}{ Female } & \multicolumn{2}{c|}{ Male } \\
\cline { 2 - 5 } & Number & Dose & Number & Dose \\
\hline Treatment 1 & 5 & $500 \mathrm{IU} / \mathrm{Kg}$ & 5 & $250 \mathrm{IU} / \mathrm{Kg}$ \\
\hline Treatment 2 & 5 & $1500 \mathrm{IU} / \mathrm{Kg}$ & 5 & $750 \mathrm{IU} / \mathrm{Kg}$ \\
\hline Treatment 3 & 5 & $3000 \mathrm{IU} / \mathrm{Kg}$ & 5 & $1500 \mathrm{IU} / \mathrm{Kg}$ \\
\hline Treatment 4 & 5 & $6000 \mathrm{IU} / \mathrm{Kg}$ & 5 & $3000 \mathrm{IU} / \mathrm{Kg}$ \\
\hline
\end{tabular}




\section{Checking for ovulation}

Female fish which were injected with different doses of HCG hormone were checked after ten (10) hrs, for ovulation and continued at one-hour intervals (Brzucka, 2004). Hence females were tested for ovulation by applying slight pressure on the abdomen towards the genital opening (eggs ooze out easily when the abdomen is gently pressed), hence females produced green-brown eggs were rated them as ovulated (ElHawarry et al., 2016). Directly latency period of each group and ovulation rate were determined.

\section{Stripping process and egg fertilization}

The stripping process occurs to collect the eggs oozed with slight pressure on abdomen in direction tail by thumb to collect the eggs into the pre-weighted plastic bowl. At the same, milt was collected from male broodfish by opening the abdomen, removed the testes and was dissected into small pieces to obtain the sperm. Milt was put on the stripped eggs, fresh water was added to activation the semen, mixed them by gently shaking of the bowl, and then eggs were rinsed in fertilizing solution (4 gram of sodium chloride and 3 gram Urea/ L water) (Saadony et al., 2014). Before this, about one gram of stripped egg from each female was put in the formalin solution $5 \%$ and storage them until determine the egg diameter and number of stripped eggs for each female. After two minutes of fertilization, eggs were washed with water and additional fresh water was added. Thereafter left the mix for 2-5 min before transport them into the incubation aquaria, after $12 \mathrm{hrs}$ from incubation the sample of eggs were taken from the central part of the incubator of each group, and then examined under microscope to determine the percentage of fertilized eggs. And then the hatching rate was determined after 24-36 hrs from incubation of egg. Fertilized eggs were incubated in aquariums with dimensions of $80 \times 50 \times 50 \mathrm{~cm}$ supplied with dechlorinated tap water. Aquarium were continuously supplied with oxygen through oxygen pumps. The fertilized eggs were placed on nylon nets suspended in the water of the aquariums. The average water quality criteria in eggs incubators are presented in Table (3).

Table (3). Water quality criteria of eggs incubators.

\begin{tabular}{|l|c|}
\hline Parameters & Measurement for eggs incubators \\
\hline Temperature, ${ }^{\circ} \mathrm{C}$ & 28 \\
\hline $\mathrm{pH}$ & 7.35 \\
\hline Dissolved oxygen, $\mathrm{mg} / \mathrm{l}$ & 7.24 \\
\hline EC*, $\mathrm{mS} / \mathrm{cm}^{* *}$ & 0.83 \\
\hline Carbonate $\left(\mathrm{CO}_{3}\right), \mathrm{mg} / \mathrm{l}$ & 21.45 \\
\hline Bicarbonate $(\mathrm{HCO} 3), \mathrm{mg} / \mathrm{l}$ & 171.45 \\
\hline Total alkalinity, $\mathrm{mg} / \mathrm{l}$ & 192.9 \\
\hline Calcium $(\mathrm{Ca}), \mathrm{mg} / \mathrm{l}$ & 35.4 \\
\hline Magnesium $(\mathrm{Mg}), \mathrm{mg} / \mathrm{l}$ & 26.85 \\
\hline Hardness $(\mathrm{Ca}+\mathrm{Mg}), \mathrm{mg} / \mathrm{l}$ & 62.25 \\
\hline * Electrical conductivity $\quad * * \mathrm{mS} / \mathrm{cm}$, millisiemens/centimeter \\
\hline
\end{tabular}




\section{Measurement Parameters:}

\section{1- The morphometric measurements.}

The morphometric measurements were carried out for each fish: body weight $(\mathrm{g})$, total length $(\mathrm{cm})$, standard length $(\mathrm{cm})$, weight of gonad $(\mathrm{g})$. The condition of the brooders was determined using the Fulton's condition factor $\left(\mathrm{K}, \mathrm{g} / \mathrm{cm}^{3}\right)$ from the relationship: Condition factor $\left(\mathrm{g} / \mathrm{cm}^{3}\right)=($ wet weight $) /\left(\right.$ total length $\left.{ }^{3}\right) \times 100$ (Htun-Han, 1978).

\section{2- Ovulation rate.}

Ovulation rate $=$ number of ovulated females/ number of injected females $\mathrm{x} 100$ (Szabo et al., 2002).

\section{3- Latency period.}

The period from injection until the start of ovulation (hrs).

\section{4- The calculation of gonadosomatic index (GSI).}

The gonadsomatic index (GSI) values were measured by recording of gonad weight and body weight of male and female separately on an electronicbalance throughout the study period. Following equation was used to determine GSI:

GSI $=$ gonads weight/ fish weight $\times 100$ (Tseng and Chan, 1982).

\section{5- The calculation of working fecundity.}

Working fecundity $=($ the number of stripped eggs/ $\mathrm{g}$ fish body weight $)$ (Kahkesh et al., 2010).

\section{6- Egg diameter.}

One gram eggs were taken from each female and fixed in 5\% formalin to determine egg diameter then, they were taken on a slide, egg diameter was determined by using an eye-piece micrometer in the binuclear at a power magnification of $10 \mathrm{X}$ and then the measurement were converted into $\mathrm{mm}$.

\section{7- Fertilization rate.}

Fertilization rate $(\mathrm{FR})=($ Number of fertilized eggs/ Total number of incubated eggs) x 100.

\section{8- Hatching rate.}

Hatching rate $=($ Number of hatched eggs $($ larvae $) /$ Total number of fertilized eggs $) \times 100$.

\section{Water quality.}

Water temperature, dissolved oxygen, $\mathrm{pH}$, electrical conductivity (EC) EC, Carbonate, Bicarbonate, Calcium (Ca), Magnesium $(\mathrm{Mg})$ and total hardness were measured in broodstock tanks and eggs incubators.

Temperature, dissolved oxygen, $\mathrm{pH}$ and $\mathrm{EC}$ were measured daily at $1 \mathrm{pm}$, by centigrade thermometer, oxygen meter (Cole Parmer model 5946), Orion digital pH meter model 201 and Conductivity meter model (YSI.SCT-33), respectively. Carbonate, Bicarbonate, Calcium $(\mathrm{Ca})$, Magnesium $(\mathrm{Mg})$ and total hardness were measured using the methods described by Centre Laboratory for Soil, Water and Plant Analysis, Faculty of Agriculture, Fayoum University (Egypt). 


\section{Statistical analysis.}

Morphometric parameters, stripping response and reproductive performance parameters were analyzed as mean \pm standard error of the mean (S.E.M). The obtained data were subjected to one-way ANOVA. Differences between means were tested at the 5\% probability level using Waller Duncan's test. All the statistical analyses were done using Statistical Package for Social Sciences program (SPSS) for Windows (SPSS, 2015) 23 , released version.

\section{RESULTS}

\section{Morphometric parameters of African catfish (Clarias gariepinus) male.}

The characteristics of male broodstock used for artificial reproduction are shown in table (4). From the table and statistical analysis indicated significant differences $(\mathrm{P} \leq 0.05)$ between treatments in body weight, total length, and standard length and condition factor. The total body weight of male broodstock range from 420-670 gram, $\mathrm{T}_{2}$ had the biggest male mean body weight $(660 \pm 10 \mathrm{~g})$ while the least mean body weight was recorded in $\mathrm{T}_{4}(431.25 \pm 11.25 \mathrm{~g})$. The total length of male brood stock used in artificial reproduction was in the range of $(42.5-51 \mathrm{~cm})$. Males in $\mathrm{T}_{1}$ recorded the highest mean total length $(49.37 \pm 1.63 \mathrm{~cm})$ while, males in $\mathrm{T}_{4}$ recorded the lowest mean total length $(43 \pm 0.5 \mathrm{~cm})$. Also in table (4) showed that the highest condition value for males that used in artificial reproduction were observed in $\mathrm{T}_{3}$ and $\mathrm{T}_{2}(0.58 \pm 0.025,0.57 \pm 0.018$ $\mathrm{g} / \mathrm{cm}^{3}$ ), respectively without significant differences between them, while, the lowest condition value for males was recorded in $\mathrm{T}_{1}\left(0.45 \pm 0.029 \mathrm{~g} / \mathrm{cm}^{3}\right)$.

Also in table (4) showed that the hormonal injection by differences doses of HCG had significant effects $(\mathrm{p} \leq 0.05)$ on males gonadsomatic index (GSI, \%) between treatments, the highest level of GSI, \% was observed in $\mathrm{T}_{4}(0.93 \pm 0.03 \%)$ followed by $\mathrm{T}_{3}$ and $\mathrm{T}_{1}(0.90 \pm 0.07,0.86 \pm 0.01 \%)$, respectively, while $\mathrm{T}_{2}$ recorded the lowest level from GSI, \% (0.73 $\pm 0.02 \%)$.

Table (4). Morphometric parameters of African catfish (Clarias gariepinus) male.

\begin{tabular}{|c|c|c|c|c|}
\hline \multirow{2}{*}{ Morphometric parameters } & \multicolumn{4}{|c|}{ Treatments } \\
\hline & $\mathbf{T}_{1}$ & $\mathbf{T}_{2}$ & $\mathbf{T}_{\mathbf{3}}$ & $\mathbf{T}_{4}$ \\
\hline Body weight, g/ male & $546.25 \pm 18.75^{b}$ & $660 \pm 10^{\mathrm{a}}$ & $551.25 \pm 23.75^{b}$ & $431.25 \pm 11.25^{\mathrm{c}}$ \\
\hline Total length, $\mathrm{cm} / \mathrm{male}$ & $49.37 \pm 1.63^{\mathrm{a}}$ & $48.75 \pm 0.75^{\mathrm{ab}}$ & $45.5 \pm 0.0^{\mathrm{bc}}$ & $43 \pm 0.5^{\mathrm{c}}$ \\
\hline Standard length, $\mathrm{cm} /$ male & $42.75 \pm 1.75^{\mathrm{a}}$ & $42.5 \pm 0.5^{\mathrm{a}}$ & $40 \pm 0.0^{\mathrm{ab}}$ & $36.5 \pm 0.5^{b}$ \\
\hline Condition factor, $\mathrm{g} / \mathrm{cm}^{3}$ & $0.45 \pm 0.029^{b}$ & $0.57 \pm 0.018^{\mathrm{a}}$ & $0.58 \pm 0.025^{\mathrm{a}}$ & $0.54 \pm 0.033^{\mathrm{ab}}$ \\
\hline GSI, $\%$ & $0.86 \pm 0.01^{\mathrm{ab}}$ & $0.73 \pm 0.02^{b}$ & $0.90 \pm 0.07^{\mathrm{ab}}$ & $0.93 \pm 0.03^{\mathrm{a}}$ \\
\hline
\end{tabular}

- (a, b, c ..) Average in the same row having different superscripts are differ significantly $(\mathrm{P} \leq 0.05)$.

$\mathrm{T}_{1}$ : male treat with $250 \mathrm{IU} \mathrm{HCG} / \mathrm{kg}$ body weight, $\mathrm{T}_{2}$ : male treat with $750 \mathrm{IU} \mathrm{HCG} / \mathrm{kg}$ body weight, $\mathrm{T}_{3}$ : male treat with $1500 \mathrm{IU}$ HCG/ kg body weight, $\mathrm{T}_{4}$ : male treat with $3000 \mathrm{IU} \mathrm{HCG} / \mathrm{kg}$ body weight). GSI: gonad somatic index 


\section{Morphometric parameters of African catfish (Clarias gariepinus) female.}

The characteristics of female broodstock are shown in table (5). From the table no significant differences $(\mathrm{P}>0.05)$ between treatments in body weight, total length, standard length and condition factor, which the body weight of female broodstock range from 505-615 gram, but $\mathrm{T}_{4}$ had the biggest female mean body weight (570 $\pm 45 \mathrm{~g}$ ), while the least mean body weight was recorded in $T_{2}(515 \pm 10 \mathrm{~g})$. The total length of female brood stock used in artificial reproduction were in the range of $41.5-49.5 \mathrm{~cm}$, but, $\mathrm{T}_{4}$ had the longest female broodstock mean total length $(46.75 \pm 2.75 \mathrm{~cm})$, while, $T_{2}$ had the shortest female broodstock mean total length $(42.75 \pm 1.25 \mathrm{~cm})$.

Table (5). Morphometric parameters of Clarias gariepinus female.

\begin{tabular}{|l|c|c|c|c|}
\hline \multirow{2}{*}{ Morphometric parameters } & \multicolumn{4}{|c|}{ Treatments } \\
\cline { 2 - 5 } & $\mathbf{T}_{\mathbf{1}}$ & $\mathbf{T}_{\mathbf{2}}$ & $\mathbf{T}_{\mathbf{3}}$ & $\mathbf{T}_{\mathbf{4}}$ \\
\hline Body weight, g/ female & $530 \pm 10$ & $515 \pm 10$ & $532.75 \pm 19.75$ & $570 \pm 45$ \\
\hline Total length, cm/ female & $43.25 \pm 0.75$ & $42.75 \pm 1.25$ & $45 \pm 0.00$ & $46.75 \pm 2.75$ \\
\hline Standard length, cm/ female & $38.25 \pm 0.75$ & $38 \pm 1$ & $39.25 \pm 0.25$ & $40.5 \pm 2.50$ \\
\hline Condition factor, $\mathrm{g} / \mathrm{cm}^{3}$ & $0.65 \pm 0.02$ & $0.66 \pm 0.04$ & $0.58 \pm 0.02$ & $0.56 \pm 0.05$ \\
\hline
\end{tabular}

$\mathrm{T}_{1}$ : female treat with $500 \mathrm{IU}$ HCG/ kg body weight, $\mathrm{T}_{2}$ : female treat with $1500 \mathrm{IU} \mathrm{HCG} / \mathrm{kg}$ body weight, $\mathrm{T}_{3}$ : female treat with $3000 \mathrm{IU} \mathrm{HCG} / \mathrm{kg}$ body weight, $\mathrm{T}_{4}$ : female treat with $6000 \mathrm{IU} \mathrm{HCG} / \mathrm{kg}$ body weight.

\section{Stripping response of the African catfish (Clarias gariepinus).}

The effect of different doses of HCG hormone on latency period (hrs), ovulated female (\%), weighted of stripped eggs $\mathrm{g} /$ female, egg diameter ( $\mathrm{mm}$ ), working fecundity (strip eggs/ $\mathrm{g}$ female) were summarized in table (6). The results showed that hormonal injection by different doses of HCG had significant effect $(\mathrm{P} \leq 0.05)$ on latency period and egg diameter. While no significant different were recorded among different doses of HCG hormone on ovulated female, \%, weighted of stripped eggs and working fecundity.

From the results in table (6) latency period ranged from 12 to $28 \mathrm{~h}$ for the ovulated four experimental treatments. The lower latency period was recorded in $\mathrm{T}_{4}(12 \mathrm{~h})$ with a significant differences from all other treatments. In contrary, the highest latency period were in $\mathrm{T}_{1}, \mathrm{~T}_{2}(28 \mathrm{~h})$ and $\mathrm{T}_{3}(22 \mathrm{~h})$. In all treatments the ovulated female was $100 \%$. No significant differences between treatments in weight of stripped eggs $\mathrm{g} /$ female, but the highest value was showed in $\mathrm{T}_{3}(50.95 \mathrm{~g} /$ female $)$ and the lowest value was observed in $\mathrm{T}_{2}$ (24.6 g/ female).

Data of the ovulated eggs diameter showed that the highest eggs diameter was showed in $\mathrm{T}_{1}$ (the lowest dose from HCG hormone) $\left(1.44 \mathrm{~mm}\right.$ ) followed by $\mathrm{T}_{3}$ and $\mathrm{T}_{2}$ with $(1.33$ and $1.31 \mathrm{~mm})$ for eggs diameter, while the lowest eggs diameter was showed in $\mathrm{T}_{4}$ (the highest dose from HCG hormone) $(1.17 \mathrm{~mm}$ ). The working fecundity in the broodstock was close to the range of 84-150 stipped eggs/g female. The recorded working fecundity (149 eggs/g female) in treatment injected with (3000 IU HCG/ kg female) was higher than those recorded in all other treatments followed by the treatment 
injected with the highest dose of HCG with (126 eggs/ g female). While the lowest value (84 and $87 \mathrm{eggs} / \mathrm{g}$ female) was observed in $\mathrm{T}_{2}$ and $\mathrm{T}_{1}$ groups injected by (1500 and 500 $\mathrm{IU} / \mathrm{kg}$ female), respectively. In figures (1 and 2) ovaries weight ( $\mathrm{g}$ ) and gonadosomatic index (GSI, \%) showed insignificant differences between treatments, but, the highest values were observed in treatment injected by $6000 \mathrm{IU} / \mathrm{kg}$ female.

Table (6). Effect of different doses of HCG on stripping response of the African catfish (Clarias gariepinus).

\begin{tabular}{|l|c|c|c|c|}
\hline \multirow{2}{*}{\multicolumn{1}{|c|}{ Parameters }} & \multicolumn{4}{c|}{ Treatments } \\
\cline { 2 - 5 } & $\mathbf{T}_{\mathbf{1}}$ & $\mathbf{T}_{\mathbf{2}}$ & $\mathbf{T}_{\mathbf{3}}$ & $\mathbf{T}_{\mathbf{4}}$ \\
\hline Latency period, hrs & $28 \pm 2^{\mathrm{a}}$ & $28 \pm 2^{\mathrm{a}}$ & $22 \pm 2^{\mathrm{a}}$ & $12 \pm 1^{\mathrm{b}}$ \\
\hline Ovulated females, \% & 100 & 100 & 100 & 100 \\
\hline $\begin{array}{l}\text { Weight of stripped } \\
\text { egg, g/ female }\end{array}$ & $27.7 \pm 6.8$ & $24.6 \pm 5.6$ & $50.95 \pm 10.35$ & $43 \pm 2.8$ \\
\hline Egg diameter, mm & $1.44 \pm 0.00^{\mathrm{a}}$ & $1.31 \pm 0.01^{\mathrm{ab}}$ & $1.335 \pm 0.05^{\mathrm{ab}}$ & $1.175 \pm 0.10^{\mathrm{b}}$ \\
\hline $\begin{array}{l}\text { Working fecundity, } \\
\text { strip eggs/g female }\end{array}$ & $87.15 \pm 25.6$ & $84.34 \pm 17.32$ & $149.3 \pm 26$ & $126.7 \pm 5.76$ \\
\hline
\end{tabular}

- (a, b, c ..) Average in the same row having different superscripts are differ significantly (P $\leq 0.05)$.

$\mathrm{T}_{1}$ : female treat with $500 \mathrm{IU}$ HCG/ kg body weight, $\mathrm{T}_{2}$ : female treat with $1500 \mathrm{IU} \mathrm{HCG} / \mathrm{kg}$ body weight, $\mathrm{T}_{3}$ : female treat with $3000 \mathrm{IU}$ HCG/ kg body weight, $\mathrm{T}_{4}$ : female treat with $6000 \mathrm{IU}$ HCG/ kg body weight.

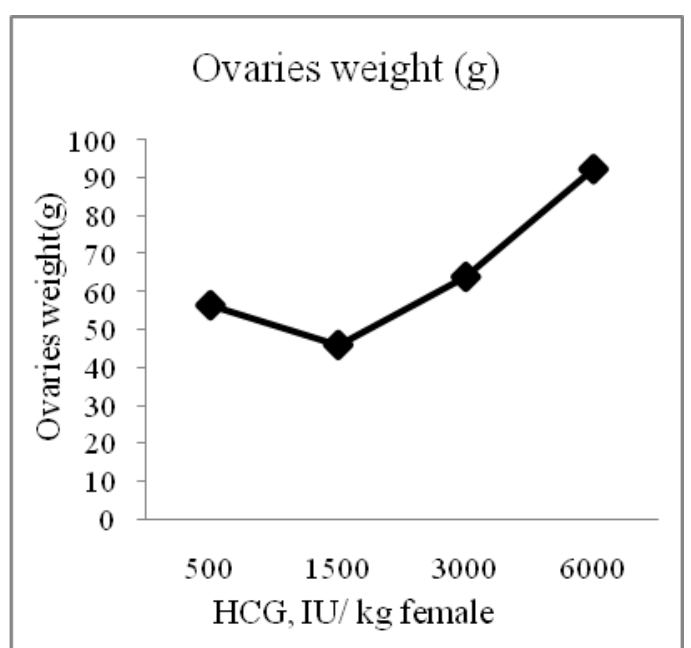

Fig 1. Changes of ovaries weight (g).

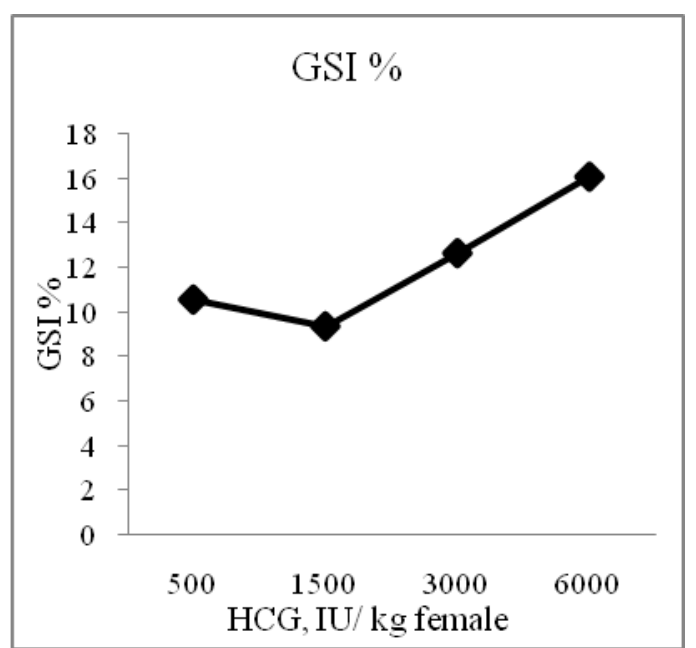

Fig 2. Changes of gonadosomatic index

\section{Reproductive performance parameters.}

Reproductive performance parameters of African catfish (C. gariepinus) under effect of injection of different doses of HCG are shown in table (7). The results showed that the induced spawning by different doses of HCG for African catfish had significant 
effects $(\mathrm{P} \leq 0.05)$ on the reproductive performance parameters (number of fertilized egg/ female, fertilization rate, number of larvae/ female, hatching rate). While, number of stripped egg/ female showed insignificant differences between treatments.

\section{Table (7). Effect of different doses of HCG on reproductive performance of African catfish (Clarias gariepinus).}

\begin{tabular}{|l|c|c|c|c|}
\hline \multirow{2}{*}{ Parameters } & \multicolumn{4}{|c|}{ Treatments } \\
\cline { 2 - 5 } & $\mathbf{T}_{\mathbf{1}}$ & $\mathbf{T}_{\mathbf{2}}$ & $\mathbf{T}_{\mathbf{3}}$ & $\mathbf{T}_{\mathbf{4}}$ \\
\hline \multirow{2}{*}{ No. of stripped egg/ female } & $45940.5 \pm$ & $43264 \pm$ & $80054 \pm$ & $71962.5 \pm$ \\
& 12709.5 & 8076 & 16800 & 2416.5 \\
\hline \multirow{2}{*}{ No. of fertilized egg/ female } & $3372.5 \pm$ & $20993 \pm$ & $59077.5 \pm$ & $60848 \pm$ \\
& $3372^{\mathrm{b}}$ & $2520^{\mathrm{b}}$ & $9107.5^{\mathrm{a}}$ & $4308^{\mathrm{a}}$ \\
\hline \multirow{2}{*}{ Fertilization rate, \% } & $10.15 \pm$ & $49.15 \pm$ & $74.7 \pm$ & $84.45 \pm$ \\
& $10.15^{\mathrm{c}}$ & $3.35^{\mathrm{b}}$ & $4.3^{\mathrm{a}}$ & $3.15^{\mathrm{a}}$ \\
\hline \multirow{2}{*}{ No. of larvae/ female } & \multirow{2}{*}{$0.0^{\mathrm{c}}$} & $12099 \pm$ & $43177.5 \pm$ & $49657 \pm$ \\
& & $997^{\mathrm{b}}$ & $4551.5^{\mathrm{a}}$ & $4878^{\mathrm{a}}$ \\
\hline \multirow{2}{*}{ Hatching rate, \% } & \multirow{2}{*}{$0.0^{\mathrm{c}}$} & $57.9 \pm$ & $73.65 \pm$ & $81.45 \pm$ \\
& & $2.2^{\mathrm{b}}$ & $3.65^{\mathrm{a}}$ & $2.25^{\mathrm{a}}$ \\
\hline
\end{tabular}

- (a, b, c ..) Average in the same row having different superscripts are differ significantly $(\mathrm{P} \leq 0.05)$.

$\mathrm{T}_{1}$ : female treat with $500 \mathrm{IU} \mathrm{HCG} / \mathrm{kg}$ body weight, $\mathrm{T}_{2}$ : female treat with $1500 \mathrm{IU}$ HCG/ kg body weight, $\mathrm{T}_{3}$ : female treat with $3000 \mathrm{IU} \mathrm{HCG} / \mathrm{kg}$ body weight, $\mathrm{T}_{4}$ : female treat with $6000 \mathrm{IU} \mathrm{HCG} / \mathrm{kg}$ body weight.

The results showed that the highest number of stripped egg was presented in $\mathrm{T}_{3}$ (80054 eggs/ female) followed by $\mathrm{T}_{4}\left(71962 \mathrm{eggs} /\right.$ female), $\mathrm{T}_{1}$ (45940 eggs/ female) and the lowest number was observed in $\mathrm{T}_{2}$ (43264 eggs/ female).

From the result in table (7) the number of fertilized eggs/ female and fertilization rate $(\%)$ were significantly different $(\mathrm{P} \leq 0.05)$ among the experimental treatments, with the highest number of fertilized eggs/ female and fertilization rate were observed in $\mathrm{T}_{4}$ (60848 fertilized eggs/ female with $84.45 \%$ ) and the lowest number of fertilized eggs/ female and fertilization rate were presented in $\mathrm{T}_{1}$ (3372 fertilized eggs/ female with $10.15 \%)$. The number of larvae/ female and hatching rate showed significant differences $(\mathrm{P} \leq 0.05)$ among different level of HCG hormone with the highest number of larvae and hatching rate in $\mathrm{T}_{4}$ (49657 larvae/ female with $81.45 \%$ ) followed by those $\mathrm{T}_{3}$ (43177 larvae/ female with $73.65 \%), \mathrm{T}_{2}$ (12099 larvae/ female with $57.9 \%$ ), while the incubation egg in $\mathrm{T}_{1}$ don't showed any hatching larvae.

\section{DISCUSSION}

Reproduction in fishes is a cyclic phenomenon and is regulated by environmental factors (exogenous) that induce internal mechanisms (endogenous) into action. In nature the fish spawning take places under good environmental conditions that are appropriate to 
the survival of the fry. Final oocyte maturation, ovulation in female and spermation in males can be controlled by both environmental and hormonal manipulation this protocol (mainly hormonal induction) have become of practical importance in aquaculture for many reasons e.g in the current fish type (African catfish), improving fecundity, synchrony the time of spawning in the most broodstock and increasing the fertilization and hatching rate (Elakkanai et al., 2015; Hawarry et al., 2016). The advantageous traits of HCG gave the possibility of accurate dosing without the need of preparation and weighing of dose, preparing and storing injections of HCG hormone is a very simple method and don't need to be injected with dopamine antagonists (Adamek, 1995).

The most popular purified gonadotropin hormone utilized to induce spawning in fish is HCG. The injected HCG in fish mimics the natural GtH synthesized and released by the fish's pituitary. Similarly just like the case with pituitary extracts, HCG bypass the brain-pituitary link, acts directly on gonads (ovaries and testes), so HCG may be more appropriate because it acts much faster, via direct induction of the gonad to induce synthesize and release sex steroid hormones which in turn act a key role in final oocyte maturation (FOM), spermiation and spawning (Rottmann et al., 1991b). It was observed in the current study that this specific hormone has successfully and accelerate induced spawning in C. gariepinus and increased in reproductive performance with the increase in HCG dosage.

During the present study minimum latency period with mean value of $(12 \mathrm{~h})$ was recorded in $\mathrm{T}_{4}$ (fish inject with $6000 \mathrm{IU} \mathrm{HCG} / \mathrm{kg}$ female) as compare to all other treatments. This similar with that obtained by El-Hawarry et al. (2016) reported that using of $4000 \mathrm{IU} / \mathrm{kg}$ from HCG showed latency period (14.3 h) in African catfish. While, the results in the current study disagree with that obtained by Ahmed (2018) reported that using of different doses from HCG (3000, 2000, $1000 \mathrm{IU} / \mathrm{kg}$ ) showed short spawning time $(6.33,9,10.33 \mathrm{~h})$, respectively in Clarias lazera.

In other hormones, Shourbela et al. (2014) reported that latency period varied from $(10.33-15 \mathrm{~h})$ when females treated with different doses from GnRHa combined with or without pimozide or dompridone in African catfish. Mamndeyati et al. (2018) indicated that using of different doses from Ovulin $(0.10,0.30,0.50 \mathrm{ml} / \mathrm{kg})$ to induce spawning of African catfish showed no significant differences between treatments in latency period with $(10 \mathrm{~h})$.

The present study showed that the suboptimal doses of 500, 1500 IU HCG/ kg injected in females was not appropriate for complete ovulation for which stripping was not easy and these showed in long latency period for which the latency period in was (28 h) when using this treatments. The higher of latency period might due to insufficient of plasma gonadotropin which this is necessary to final maturation and ovulation (Billard et al., 1984; Sahoo et al., 2005). 
The differences occurred in latency period may be due to the kind of hormones, the doses of hormonal injection that used, water parameter specially temperature, time of injection and fish species.

The results of ovulated females $(\%)$ recorded in the present study were greater than those reported for Barbuss harpeyi (Kahkesh et al., 2010); C. gariepinus (Saadony et al., 2014) who reported that the ovulation index (\%) was ranged between 38 to $66 \%$ for which the ovulation index was $(70.25$ and $66.56 \%)$ in the fish groups injected with (1000, 3000 IU HCG/ kg female), respectively.

Meanwhile, the ovulation percentage in the present study was one hundred percent in all treatments except the fish in control group who failed to ovulate with zero \% ovulation and this result may be due to lessen in plasma gonadotropin (GTH) level in those females where, GTH is necessary to start the final proceedings egg maturation and ovulation.

Sahoo et al. (2008) demonstrated that the good stripping response with the highest egg weight was present in C. batrachus when the hormonal injection was (3000-4000 IU HCG/ kg female) combination with latency period (14-23 h). While, Akar et al. (2010) reported that the ovulation index was $90 \%$ in common carp that injected with two doses from HCG hormone (the first and second doses were similar $1000 \mathrm{IU} / \mathrm{kg}$ female).

The weight of stripped eggs in the present study was in the range between 24 to 50 $\mathrm{g} /$ female, where, the highest value of stripped eggs (50.95 g/ female) was observed in $\mathrm{T}_{3}$ (3000 IU HCG/ kg female) followed by $\mathrm{T}_{4}$ (6000 IU HCG/ kg female) with $43.28 \mathrm{~g} /$ female. While, the minimum weights of stripped eggs were presented in $T_{1}$ and $T_{2}$ with (27.27 and $24.6 \mathrm{~g} /$ female, respectively. This similar with that obtained by Ahmed (2018) who found that the egg weights that obtained in C. gariepinus by using (1000, 2000 and $3000 \mathrm{IU}$ HCG/ $\mathrm{kg}$ fish) was (9.67, 25.67 and $63 \mathrm{~g}$ ), respectively. In addition, the egg weights were ranged between (30 - $67 \mathrm{~g}$ ) when females of African catfish stimulated with different doses from GnRHa combined with or without pimozide or dompridone with significant differences among treatments (Shourbela et al., 2014). The egg weights in the current study was higher than those observed for $C$. gariepinus with Adebayo and popoola (2008) who reported that when stimulated spawning in females with weight in range between 530 to $540 \mathrm{~g}$ by using (Frog pituitary extract, $0.5 \mathrm{ml}$ ovaprim/ $\mathrm{kg}$ fish and C. gariepinus pitiutary extract) the egg weights was (26.26, 18 and $21.28 \mathrm{~g} / \mathrm{female})$, respectively.

According to the present results the working fecundity in the broodstock was the highest value (149.3 egg/ g female) was recorded in the fish injected with 3000 IU HCG/ $\mathrm{g}$ female) followed by $6000 \mathrm{IU}$ HCG/ $\mathrm{g}$ female (126.7 egg/ $\mathrm{g}$ female) with insignificant different between treatments. These results were higher than those obtained in Benni fish (Barbus sharpeyi) by Kahkesh et al. (2010) who reported that working fecundity was (33, 56, 34, and 33 stripped eggs/ g female) when Barbus sharpeyi females induction to spawning by different matrials (not inject, $10 \mu \mathrm{LHRHa} / \mathrm{kg}, 10 \mu \mathrm{LHRHa} / \mathrm{kg}$ plus $2 \mathrm{mg} /$ 
Carp pitiutary extract/ $\mathrm{kg}$ female, $0.5 \mathrm{ml}$ Ovatide/ $\mathrm{kg}$ female and $0.5 \mathrm{ml}$ Ovaprim/ $\mathrm{kg}$ female), respectively.

In the present study, the results showed that the fertilization rate was significantly different $(\mathrm{P} \leq 0.05)$ among the experimental treatments, which the fish group injected by $6000 \mathrm{IU} / \mathrm{kg}$ female had the highest fertilization rate $(84.5 \%)$, while the lowest fertilization rate was recorded in $\mathrm{T}_{1}$ (the fish group inject by $500 \mathrm{IU} / \mathrm{kg}$ female (10\% fertilization rate). These results agree with results of Ahmed and Manofal (2017) who found that when the females of C. gariepinus injected by different doses from HCG (500, 1500, 2250, 2500 $\mathrm{IU} / \mathrm{kg}$ fish) found that the increase in the hormonal dose that used from HCG led to an increase in the fertilization rate $(0,65,60,75 \%)$, respectively. Also, Maradun et al. (2018) Who reported that the dosage of the hormone administered influenced the fertilization rate as the increase in dosage resulted in more fertilization percentage and found that the fertilization percentage was higher $(88.12 \%)$ in fish group injected with higher dose of Ovulin $(0.7 \mathrm{ml} / \mathrm{kg}$ fish) than those injected with lower dose from Ovulin $(0.3$ and $0.5 \mathrm{ml} / \mathrm{kg}$ fish) with $(72.73$ and $80.62 \%)$, respectively when induced spawning in C. gariepinus.

Similarly several studies carried out for induction spawning in African catfish $(C$. gariepinus). Saadony et al. (2014) found that the fertilization rate was (40, $72.5 \%)$ when females of African catfish injected by $(1000,3000 \mathrm{IU}$ HCG/ kg fish). And El-Hawarry et al. (2016) indicted that the using of (4000 IU HCG/ kg fish, 4000 plus $10 \mathrm{mg}$ Dopamine antagonist) in C. gariepinus showed fertilization rate $(85.1,82.2)$.

In the other hand, Ahmed (2018) found that no significant differences in fertilization rate, $\%(86,85,87 \%)$ when the females of $C$. gariepinus were stimulate to spawning by using (3000, 2000, $1000 \mathrm{IU}$ HCG/ kg fish), respectively.

In the present study, the results indicated that the increasing in concentration of HCG doses that used to induce spawning caused the increasing in percentage of hatching. Meanwhile, the hatching rate in the current study showed significant differences among treatments with the highest value $(81.45 \%)$ was recorded in $\mathrm{T}_{4}$ (females injected with $6000 \mathrm{IU} \mathrm{HCG} / \mathrm{kg})$ followed by $\mathrm{T}_{3}$ and $\mathrm{T}_{2}(3000,1500 \mathrm{IU} \mathrm{HCG} / \mathrm{kg})$ with $(73.65,57.9 \%)$, respectively. This results are similar with Maradun et al. (2018) who found that the rates of $(74.10,79.84$ and $82.07 \%)$ were observed in the hatching rate when the African catfish groups injected by increasingly doses from Ovulin $(0.3,0.5$, and $0.7 \mathrm{ml} / \mathrm{kg}$ female weight), respectively.

El-Hawarry et al. (2016) reported that the hatching percentage was $(85.1,83.7 \%)$ when induced spawning in C. gariepinus by using (4000 IU HCG/ kg fish, 4000 plus 10 mg Dopamine antagonist), respectively. Furthermore the hatching rate that obtained by El-Hawarry et al. (2016) with using (4000 IU HCG/ kg fish) was higher than those obtained when using $40 \mu \mathrm{g} \mathrm{GnRH}-\mathrm{a}$ with or without $10 \mathrm{mg}$ Dopamine antagonist. with (81.9 and $75.2 \%$ ), respectively. While, Shourbela et al. (2014) demonstrated that the hatching rate was ranged between (70.02 to $89.17 \%$ ) when African catfish females 
injected by different doses from GnRH-a combined with or without pimozide or domperidone.

Sahoo et al. (2009) tested five HCG doses in combinations with five latency periods during stimulate spawning of catfish (C. batrchus) and reported that the HCG dosage $3000 \mathrm{IU} / \mathrm{kg}$ in combined with latency period $14-23 \mathrm{~h}$ and $4000 \mathrm{IU} / \mathrm{kg}$ in combined with latency period $14-17 \mathrm{~h}$ were better to reduce the deformed larvae among hatchling.

In the other hand, Ahmed (2018) reported that the hatching rate showed insignificant differences between treatments injected by (1000, 2000, 3000 IU HCG/ kg fish) with hatching rate in average 82 to $83 \%$ in African catfish.

In the present study, the failure of fertilized eggs to hatch in fish group injected with $500 \mathrm{IU}$ HCG/ kg female weight may suggest that insufficient hormonal dose used to reach the full maturity of eggs in this group.

\section{CONCLUSION}

From results of the present study the hormonal injection by $6000 \mathrm{IU}$ HCG/ kg female was some advantages over the other treatments in terms of higher ovaries weight, gonadsomatic index, fertilization rate and hatching rate and the latency period recorded the lowest time in African catfish females. It suggest that the highest doses from hormonal therapy, that tested to induced spawning of African catfish in the current study caused speed up in ovarian development and ovulation. Because of this process, the latency period recorded the lowest time with $6000 \mathrm{IU}$ HCG/ kg female and leaded to accelerated hormonal stimulation, caused in increasing in gonadsomatic index but this leaded to decrease in egg diameter. The failure of fertilized eggs to hatch in fish group injected with $500 \mathrm{IU}$ HCG/ kg female weight may suggest that insufficient hormonal dose used to reach the full maturity of eggs in this group. It was observed, HCG hormone has successfully and accelerate induced spawning in African catfish (Clarias gariepinus) and increased in reproductive performance with the increase in HCG dosage.

\section{REFERENCES}

Adamek, J. (1995). Rozrodi podchow wyegn surna a fry kanskiego (Clarias garipinus). Przegl. Ryb., 1: 36-42.

Adebayo, O.T. and popoola, O.M. (2008). Comparative evaluation of efficacy and cost of synthetic and non-synthetic hormone for artificial breeding of African catfish Clarias gariepinus (Burchell, 1822). Journal of Fisheries and Aquatic science, 3(1): 66-71

Ahmed, A.M.A. and Manofal, A.M.A. (2017). Induced breeding of Clarias lazera using hormones of HCG and SGnRHa Neelain University- Khartoum- Sudan. Sch. J. Agric. Vet. Sci., 4(9): 327-330 
Ahmed, A.M.M. (2018). Effect of induced breeding of Clarias lazera using hormones of HCG. American Journal of Marine Research and Reviews, 1:2 ,DOI: 10.28933/ajmrr-2018-02-2801.

Akar, A.M.; Farag, M.E. and Ali, M.A. (2010).Comparative study showing the effect of injection with different doses of sex steroid hormones on reproductive performance of common carp (Cyprinus carpio L.) and grass carp (Ctenopharyngodon idella). Arabian Aquaculture Society, 5(1): 89-100

Alaiwa, F.A. (1982). Fish farms in fresh water, establishment and management (Egypt).

Badran, M.F.; El-Danasoury, M.A.; Sharaf, S.M. and Hassan, A.M. (2019). Biological measurements and hormonal profile in female Gilthead sea bream (Sparus aurata) in response to Human Chorionic Gonadotropin (HCG) injection. Suez Canal Veterinary Medical Journal, 24(1): 103-112

Billard, R.; Bieniarz, K.; Peter, R.E.; Sokolowska, M.; Weil, C. and Crim, L.W. (1984). Effects of LHRH and LHRH-a on plasma GtH levels and maturation/ovulation in the common carp Cyprinus carpio, kept under various environmental conditions. Aquaculture, 41: 245-254

Brzuska, E. (2004). Artificial spawning of carp (Cyprinus carpio L.): differences between the effects of reproduction in females of Hungarian, Polish and French origin treated with carp pituitary homogenate or [D-Tle6, ProNHEt9] GnRH (Lecirelin). Aquacul Res., 35(14): 1318-1327.

Brzuska, E.; Ráczkevi, R.J.; Adamek, J. and Radics, F. (1999). Preliminary investigation on the influence of different hormone treatments on the ovulation, embryonic survival, and larval morphology in African catfish (Clarias gariepinus Burchell) (in Hungarian with English summary). Halászat, 2: 88-92.

Brzuske, E. (2003). Artificial propagation of African catfish (Clarias gariepinus): differences between reproduction effects after stimulation of ovulation with carp pituitary homogenate or GnRH-a and dopaminergic inhibitor. Czech J. Anim. Sci., 48(5): 181-190

Di Maggio, M.A.; Broach, J.S. and Ohs, C.L. (2014). Evaluation of Ovaprim and Human Chorionic Gonadotropin doses on spawning induction and egg and larval quality of Pigfish, Orthopristis chrysoptera. Journal of the World Aquaculture Society, 45(3): 243-257.

DOF (Department of Fisheries) (2014). National fish week compendium. Department of Fisheries Ministry of Fisheries and Livestock, Dhaka, Bangladesh, pp. 144.

Elakkanai, P.; Francis, T.; Ahilan, B.; Jawahar, P.; Padmavathy, P.; Jayakumar, N. and Subburaj, A. (2015). Role of GnRH, HCG and Kisspeptin on reproduction of fishes. Indian Journal of Science and Technology, 8(17): 1-10

El-Hawarry, W.N.; AbdEl-Rahman, S.H. and Shourbela, R.M. (2016). Breeding response and larval quality of African catfish (Clarias gariepinus, Burchell 1822) using different hormones/hormonal analogues with dopamine antagonist. Egyptian Journal of Aquatic Research, 42: 231-239. 
FAO (2020). The state of world fisheries and aquaculture 2020. Sustainability in action. Rome.

Gadisa, N.; Wakjira, M.; Negisho, T. and Endebu, M. (2017). Spawning response of African catfish (Clarias gariepinus (Burchell 1822), Clariidae: Teleost) exposed to different piscine pituitary and synthetic hormone. International Journal of Fisheries and Aquatic Studies, 5(2): 264-269.

Htun-Han, M. (1978). The reproductive biology of the dab Limanda limanda (L.) in the North Sea: gonosomatic index, hepatosomatic index and condition factor. J. Fish Biol., 13: 369-378.

Kahkesh, F.B.; Feshalami, M.Y.; Amiri, F. and Nickpey, M. (2010). Effect of Ovaprim, Ovatide, HCG, LHRH-a2, LHRH-a2+CPE and Carp pituitary in Benni (Barbus sharpeyi) artificial breeding. Global Veterinaria, 5 (4): 209-214

Mamndeyati, U.N.; Otebe, J.A.; Ibagye, O.M. and Agatsa, T.D. (2018). Effect of varying dosage of Ovulin on the breeding performance of Clarias gariepinus in improvised hatchery tanks in Benue State University, Makurdi, Benue State, NIGERIA. FUW Trends in Science \& Technology Journal, 3 (1): 230-233.

Maradun, H.F.; Umar, F.; Ibrahim, A.; Mubarak, A.; Zarau, I.J. and Muhammad, S.A. (2018). Effect of different doses of Ovulin hormone on the induced breeding performance of Clarias gariepinus. Journal of Animal and Veterinary Sciences, $5(1): 1-5$

Marimuthu, K. (2019). A short review on induced spawning and seed production of African catfish Clarias gariepinus in Malaysia. IOP Conf. Ser.: Earth. Environ. Sci., 348: 1-6

Mehrim, A.I.; Abdelhamid, A.M.; Radwan, I.A. and Abdelhamid, A.F. (2014). Comparative study for different sources of reproductive stimulating materials and their effects on the reproductive performance of African catfish Clarias gariepinus (Burchell, 1822). Asian Journal of Animal and Veterinary Advances, 9 (7): 414-427.

Ngueku, B.B. (2015). The efficacy of synthetic and non-synthetic hormones in the induce spawning of the African catfish (Clarias gariepinus). International Journal of Fisheries and Aquatic Studies, 3(1): 34-37.

Rahman, S.M.B.; Mahmud, Z.; Ahmed, F.; Ghosh, A.K. and Sabbir, A.W. (2011). Induced breeding, embryonic and larval development of comet gold fish (Carassius auratus). Electronic Journal of Biology, 7(2): 32-39.

Rottmann, R.W.; Shireman, J.V. and Chapman, F.A. (1991a). Introduction to hormoneinduced spawning of fish, SRAC Publication No. 421

Rottmann, R.W.; Shireman, J.V. and Chapman, F.A. (1991b). Hormonal control of reproduction in fish for induced spawning. SRAC Publication No. 424.

Rutaisire, J. and Booth, A.J. (2004). Induced ovulation, spawning, egg incubation, and hatching of the Cyprinid fish Labeo victorianus in captivity. Journal of the World Aquaculture Society, 35(3): 383-391.

Saadony, S.A.M.; Eldanasoury, M.A.; Ali, B.A. and Sharaf, S.M. (2014). Seasonal reproductive biology and artificial propagation of female African catfish (Clarias 
gariepinus) after hormonal stimulation. Journal of Animal, Poultry \& Fish Production, Suez Canal University, (2): 21-31.

Sahoo, S.K.; Girl, S.S. and Sahu, A.K. (2005). Effect on breeding performance and egg quality of Clarias batrachus (Linn.) at various doses of ovatide during spawning induction. Asian Fisheries Science, 18: 77-83.

Sahoo, S.K.; Giri, S.S., Chandra, S. and Mohapatra, B.C. (2008). Evaluation of spawning performance of Asian catfish Clarias batrachus at different dose of HCG and latency period combinations. Turkish Journal of Fisheries and Aquatic Sciences, 8: 249-251.

Sahoo, S.K.; Girl, S.S.; Chandra, S. and Sahu, A.K. (2009). Observation on larval deformity duding induced spawning of Walking catfish Clarias Batrachus (Actinopteryg II: Siluriformes: Clariidae), at different combinations of Human Chorionic Gonadotropin dose and latency period. ACTA Ichthtologic Et Piscatoria, 39 (1): 43-45

Shourbela, R.M.; Abd-El-Latif, A.M. and Abd-El-Azem, M.A. (2014). Induced spawning of African catfish, using (GnRHa) combined with Dopamine Antagonists. Benha Veterinary Medical Journal, 27(1): 25-35.

Shourbela, R.M.; Tohamy, H.G. and El-Hawarry, W.N. (2020). Induced spawning of African catfish (Clarias gariepinus Burchell 1822) after pre-spawning prophylactic disinfection; the breeding performance and tissue histopathological alterations are under scope, Iranian Journal of Fisheries Sciences, 19(1): 309-324.

SPSS (2015). Statistical Package for Social Science (for Windows). Release 23 Copyright (C), SPSS Inc., Chicago, USA.

Sukendi.; Windarti.; Putra, R.M. and Eddiwan. (2019). Hormone induced spawning and feeding conditions for Betok fish (Anabas testudineus). Eurasia. J. Biosci., 13: 121-125.

Szabo, T.; Modgyasszay, C.S. and Horvath, L. (2002). Ovulation induction in nase (Chondrostom anasus). Using pituitary extract or $\mathrm{GnRH}$ analogue combined with domperidone. Aquaculture, 203: 389-395.

Tanaka, H.; Kagawa, H.; Ohta, H.; Unuma, T. and Nomura, K. (2003). The first production of Glass eel in captivity: fish reproductive physiology facilitates great progress in aquaculture. Fish Physiol. Biochem., 28: 493-497.

Tseng, W.Y. and Chan, K.L. (1982). The productive biology of the Rabbit fish in Hong Kong. J. World Maricul. Soc., 13: 313-321.

Tyor, A.K. and Pahwa, K. (2017). Research article ovarian development of African sharptooth catfish (Clarias gariepinus, Burchell 1822) from Delhi segment of River Yamuna. J. Fish. Aquatic. Sci., 112(3): 117-126. 


\section{ARABIC SUMMARY \\ تاثير حقن أسماك القرموط الافريقى بجرعات مختلفة من هرمون الجونادوتروبين البشري (HCG) علائ

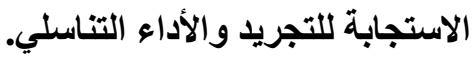 \\ سيد ربيع سيد زيدان' ، حامد حامد السيد صالح'، أحمد إبراهيم صميدة' ، رمضان محمد أبوزيد' و صبحي محمود علام' \\ ا ا قسم الانتاج الحيو اني، كلية الزر اعة، جامعة الفيوم، مصر.

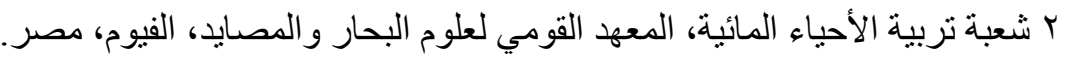

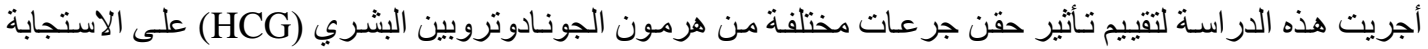

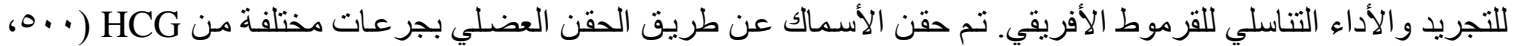

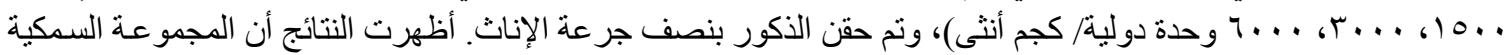

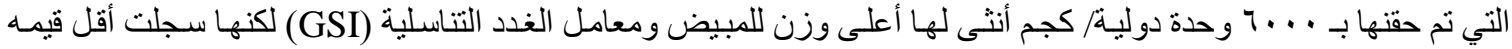

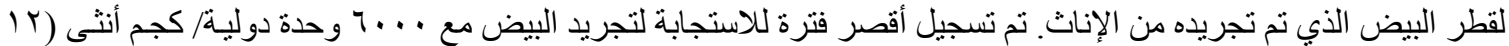

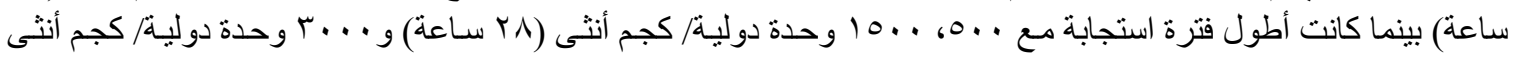

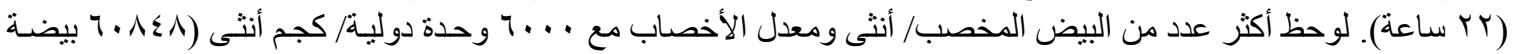

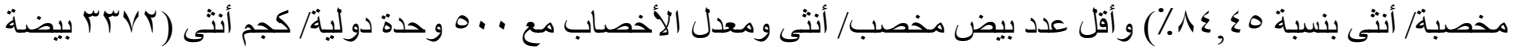

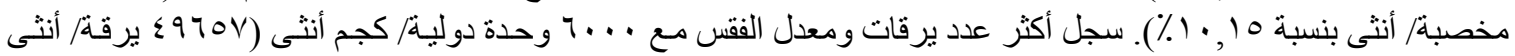

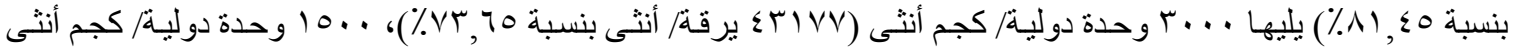

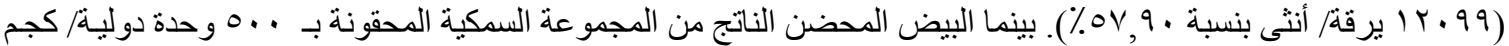

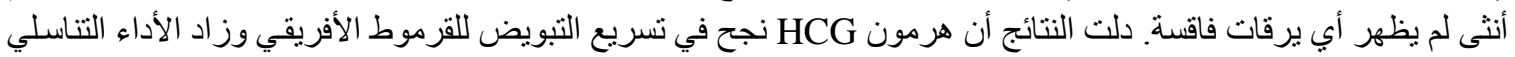

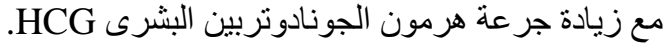

